may lead to cases in other patients or healthcare workers. In case an infection is not correctly attributed to a nosocomial origin, the cost might not be charged to the appropriate payer. Finally, the nosocomial origin of certain infections might be found at a later stage and may trigger lawsuits. 18 Transmission of HIV and HCV infections through blood transfusions illustrates this important potential problem.

\section{REFERENCES}

1. Geberding JL. The infected health care provider. $N$ Engl J Med 1996;334:594-595.

2. Bronowicki JP, Venard V, Botte C, Monhoven N, Gastin I, Chome L, et al. Patient-to-patient transmission of hepatitis $\mathrm{C}$ virus during colonoscopy. N Engl J Med 1998;337:237-240.

3. Favero MS, Pugliese G. Infections transmitted by endoscopy: an international problem. Am J Infect Control 1996;24:343-345.

4. Heptonstall JE. Transmission of hepatitis B to patients from four infected surgeons without hepatitis B e antigen. N Engl J Med 1997;336: 178-184.

5. Olmsted RN. What is the risk of acquiring hepatitis $\mathrm{C}$ for health care workers and what are the recommendations for prophylaxis and followup after occupational exposure to hepatitis $\mathrm{C}$ virus ? Am J Infect Control 1996;24:411-415.

6. Esteban JI, Gomez J, Martell M, Cabot B, Quer J, Camps J, et al. Transmission of hepatitis $\mathrm{C}$ virus by a cardiac surgeon. $N$ Engl $\mathrm{J} \mathrm{Med}$ 1996;334:555-560.

7. Olmer M, Bouchouareb D, Zandotti C, de Micco C, de Lamballerie X. Transmission of the hepatitis $\mathrm{C}$ virus in an hemodialysis unit: evidence for nosocomial infection. Clinical Nephrology 1996;47:263-270.

8. Robert LM, Chamberland ME, Cleveland JL, Marcus R, Gooch BF, Srivastava PU, et al. Investigations of patients of health care workers infected with HIV. Ann Intern Med 1995;122:653-657.

9. Dooley SW, Villarino ME, Lawrence M, Salinas L, Amil S, Rullan JV, et al. Nosocomial transmission of tuberculosis in a hospital unit for HIVinfected patients. JAMA 1992;267:2632-2634.

10. Kenyon TA, Ridzon R, Luskin-Hawk R, Schultz C, Paul WS, Valway SE, et al A nosocomial outbreak of multidrug-resistant tuberculosis. Ann Intern Med 1998;127:32-36.

11. Guerrero A, Cobo J, Fortún J, Navas E, Quereda C, Asensio A, et al. Nosocomial transmission of Mycobacterium bovis resistant to 11 drugs in people with advanced HIV-1 infection. Lancet 1997;350:1738-1742.

12. Pearson ML, Jereb JA, Frieden TR, Crawford JT, Davis BJ, Dooley SW, et al. Nosocomial transmission of multidrug-resistant Mycobacterium tuberculosis. Ann Intern Med 1992;117:191-196.

13. Couldwell DL, Dore GJ, Harkness JL, Marriott DJE, Cooper DA, Edwards R, et al. Nosocomial outbreak of tuberculosis in an outpatient HIV treatment room. AIDS 1996;10:521-525.

14. Menzies D, Fanning A, Yuan L, Fitzgerald M. Tuberculosis among health care workers. N Engl J Med 1995;332:92-98.

15. Blumberg HM, Watkins DL, Berschling JD, Antle A, Moore P, White N, et al. Preventing the nosocomial transmission of tuberculosis. Ann Intern Med 1995; 122:658-663.

16. Allan B, Tuft S. Transmission of Creutzfeldt-Jakob disease in corneal grafts: observing the exclusion criteria for donated grafts should ensure the risk is small. BMJ 1997;315:1553-1554.

17. McGreevy Steelman V. Creutzfeldt-Jakob diseases: recommendations for infection control. Am J Infect Control 1994;22:312-318.

18. Herwaldt LA, Pottinger JM, Carter CD, Barr BA, Miller ED. Exposure workups. Infect Control Hosp Epidemiol 1997;18:850-871.

19. Valenti WM. Selected viruses of nosocomial importance. In: Bennett JV, Brachman PS, eds. Hospital Infections. 4th ed. Philadelphia, PA: Lippincott-Raven; 1998:637-664.

20. Weigelt JA, Dryer D, Haley RW. The necessity and efficiency of wound surveillance after discharge. Arch Surg 1992;127:77-82.

21. Bean B, Rhane FS, Hughes RS, Weiler MD, Peterson LR, Gerding DN. Influenza B: hospital activity during a community epidemic. Diagn Microbiol Infect Dis 1983;1:177-183.

22. Holladay RC, Campbell GDJ. Nosocomial viral pneumonia in the intensive care unit. Clinics in Chest Medicine 1995;16:121-133.

23. Centers for Disease Control and Prevention. Guidelines for prevention of nosocomial pneumonia. MMWR 1997;46:1-79.

24. Ta AC, Stout JE, Yu VL, Wagener MM. Comparison of culture methods for monitoring Legionella species in hospital potable water systems and recommendations for standardization of such methods. J Clin Microbiol 1995;33:2118-2123.

\title{
Clindamycin Restriction Decreases Clostridium difficile-Associated Diarrhea
}

\section{Gina Pugliese, RN, MS Martin S. Favero, PhD}

Investigators from Hunter Holmes McGuire Veterans' Affairs Medical Center (VAMC) conducted a prospective, observational cohort study to characterize the impact of hospitalwide clindamycin restriction on the incidence of Clostridium difficile-associated diarrhea (CDAD).

Clinical data were corrected on hospitalized patients with symptomatic diarrhea, and data on antibiotic use were obtained from hospital pharmacy records. An outbreak of CDAD was caused by a clonal isolate of clindamycin-resistant $C$ difficile and was associated with increased use of clindamycin. Hospitalwide requirement of approval by an infectious disease consultant of clindamycin use led to an overall reduction in clindamycin use, a sustained reduction in the mean number of cases of CDAD (11.5 cases/month vs 3.33 cases/month; $P<.001$ ), and an increase in clindamycin susceptibility among $C$ difficile isolates ( $9 \%$ vs $61 \% ; P<.001)$. Although a parallel increase was noted in the use of other antibiotics with antianaerobic activity, including cefotetan, ticarcillin-clavulanate, and imipenem-cilastin, the hospital realized overall cost savings due to the decreased incidence of CDAD.

The authors concluded that hospital formulary restriction of clindamycin is an effective way to decrease CDAD. It also can lead to a return in clindamycin susceptibility among isolates and can effect cost savings to the hospital.

FROM: Climo MW, Israel DS, Wong ES, Williams D, Coudron P, Markowitz SM. Hospital-wide restriction of clindamycin: effect on the incidence of Clostridium difficile-associated diarrhea and cost. Ann Intern Med 1998;128(12 pt 1):989-995. 